Migrant Labor, Folklore, and Resistance in Hurston's Polk County: Reframing Mules and Men

Author(s): David G. Nicholls

Source: African American Review, Vol. 33, No. 3 (Autumn, 1999), pp. 467-479

Published by: Indiana State University

Stable URL: https://www.jstor.org/stable/2901213

Accessed: 25-01-2019 06:09 UTC

JSTOR is a not-for-profit service that helps scholars, researchers, and students discover, use, and build upon a wide range of content in a trusted digital archive. We use information technology and tools to increase productivity and facilitate new forms of scholarship. For more information about JSTOR, please contact support@jstor.org.

Your use of the JSTOR archive indicates your acceptance of the Terms \& Conditions of Use, available at https://about.jstor.org/terms

Indiana State University is collaborating with JSTOR to digitize, preserve and extend access to African American Review 


\section{Migrant Labor, Folklore, and Resistance in Hurston's Polk County: Reframing Mules and Men}

I $\mathrm{n}$ a recent article proposing a rethinking of the historiography of black working-class politics in the Jim Crow South, Robin Kelley has suggested that the historian's attention should shift from a focus on political leaders to a consideration of "everyday acts of resistance" carried out by working people (" 'We Are

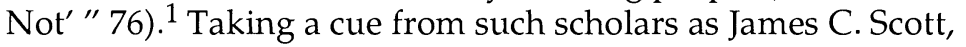
Michel de Certeau, and Eugene Genovese, Kelley sets out to find the "hidden transcript" of a "dissident political culture" in the urban South during the 1930s and 1940s (77). ${ }^{2}$ He explains his rationale for doing so:

\begin{abstract}
Beneath the veil of consent lies a hidden history of unorganized, everyday conflict waged by African-American working people. Once we explore in greater detail those daily conflicts and the social and cultural spaces where ordinary people felt free to articulate their opposition, we can begin to ask the questions that will enable us to rewrite the political history of the Jim Crow South to incorporate such actions and actors. (76)
\end{abstract}

Kelley's article discusses forms of resistance as they occurred at home, at work, at play, and in the public at large so as to force a reconsideration of how action in daily life contributed to political change in the South.

My aim in this article is to use Kelley's study of working-class resistance to launch a revisionary reading of the narrative frame of Zora Neale Hurston's Mules and Men (1935). Indeed, Kelley's article begins with an epigraph from Hurston's book in which she debunks the "seeming acquiescence" of the smiling Negro laborer. In Hurston's collection of folklore, I will argue, the "hidden transcript" of everyday resistance is exposed through the narrative frame with which she surrounds her transcription of "folk"3 tales. This articulation of resistance through folklore is most evident in the middle pages of her book, in which Hurston describes her visit to a lumber camp in Polk County, Florida. In this section, Hurston at first experiences the workers' efforts to resist her intrusion on the scene because they think she is a detective. As she gains their acceptance, however, she is able to record their tales. She displays the migrant laborers telling tales on the job, and in so doing she shows how the tales form a discourse of dissent relating to the conditions of labor in the company town.

When Hurston is accepted in the camp, her narrative voice shifts from first-person-singular to third-person. As her authorial presence recedes, the narrative shows us how folklore could be used as a form of resistance in the Jim Crow South.

\section{David G. Nicholls is Assistant Professor of American Literature and Culture at Bilkent University. Between 1991 and 1995, he edited Chicago Review, and he is the co-editor of The Penguin New Writing in India. This essay is part of a book, Conjuring the Folk: Forms of Modernity in African America, which is forthcoming from the University of Michigan Press. This larger project has been sponsored by the Mellon Foundation; the Rockefeller Foundation; the Center for Afroamerican and African Studies at the University of Michigan; and the Center for the Study of Race, Politics, and Culture at the University of Chicago. Professor Nicholls would like to thank both foundations and both universities for their support. He would also like to thank Robert Hemenway, Loren Kruger, Christopher Roth, Angela Sorby, and Kenneth Warren for their assistance during various stages of the project.}




\section{Autobiography, Ethnography, and the Narrative Frame}

$\mathrm{H}$ urston's narrative frame has long been a topic of study for readers of Mules and Men, and it is worth considering the critical history on this topic before pursuing a revisionary reading of it. Rather than presenting a compendium of "folk" tales collected from the field, Hurston weaves the tales into an overarching narrative featuring her travels to her hometown of Eatonville, Florida, to neighboring Polk County, and to New Orleans. Since the link between these three sites is her traveling, observing self, most studies of the book's narrative frame have centered on the relation between autobiography and ethnography in the text. Her biographer, Robert Hemenway, spells out the questions that animate this line of inquiry:

\begin{abstract}
Is Mules and Men about Zora Hurston or about black folklore? If the former, the self-effacement makes the reader want to know more about what was going on in her mind, more about her reaction to the communities that embraced her. If the latter, there is a need for folklore analysis. (167)
\end{abstract}

Hurston's text would seem to blend aspects of the autobiographical travelogue with aspects of the ethnographic study, and Hemenway's questions suggest that the expectations of both genres remain unmet in Mules and Men. Her narrative frame, he argues, frustrates the reader's attempt to understand her relation to the "folk" she is describing.

Hurston's frustration of generic expectations has been a source of excitement for many feminist scholars. Cheryl Wall claims that "the subtext of Mules and Men is the narrative of a successful quest for female empowerment" ("Mules" 661), 4 whereas Priscilla Wald claims that Hurston was "uniquely situated to explore the critical possibilities of marginality" (79). These arguments take Hurston's departure from traditional folkloric form as subversive, even if such subversion is submerged, subtextual, and marginal..$^{5}$ Barbara Johnson has complicated this approach, noting that "one of Hurston's most memorable figurations of the inside/outside structure is her depiction of herself as a threshold figure mediating between the allblack town of Eatonville, Florida, and the big road traveled by passing whites" (318). As Hurston mediates between these two spheres, Johnson argues, she also complicates the inside/outside opposition, yielding "difference as a suspension of reference" (328). ${ }^{6}$ In all of these accounts, Hurston's presence in the book is shown to trouble the ethnographic endeavor. And her trouble-making is shown to be inspired by her marginality and her feminism in these arguments. ${ }^{7}$

Hurston's formal innovation has recently provoked a great deal of discussion among scholars whose primary interest is in folklore and ethnography. Some critics, citing an aspiration for science and objectivity in folklore studies, have seen Hurston's narrative frame as compromising the book. ${ }^{8}$ Many others have seen Hurston's break with scientism as exemplary, given the postmodern critique of ethnography. Sandra Dolby-Stahl, for example, has argued that Hurston attends to the concerns articulated in the collection Writing Culture: "Long before Clifford and Marcus and other contemporary scholars brought such concerns out into the light of day, Zora Neale Hurston showed us how a good writer does it best-with a writer's skill and literary objectives taking precedence over the conventions of scholarship" (52). Dolby-Stahl argues that Hurston submerges technical jargon in dialect, making her scientific analysis more amenable for a literary audience, thus slipping in an argument in the subtext. Other scholars have read Hurston's use of "literary" devices as a way of experimenting with ethnographic form: Her self-reflexive ges- 
tures deconstruct ethnographic authority; introduce multiple, partial truths; and trouble the academy's relation to minority ethnographers. ${ }^{9}$ These analyses of the narrative frame of Mules and Men as secretly subversive are homologous with the feminist arguments about the book I have discussed.

My brief synopsis of the extant work on Hurston is meant to show that the critical exploration of Hurston's narrative frame has focused almost exclusively on the relation between autobiography and ethnography. While this interpretive work has done much to question the certainty of the ethnographic encounter and to raise important questions about gender, it has also tended to oversimplify the role of the narrative frame in Mules and Men. This oversimplification, I will argue, has led readers to miss the book's presentation of everyday forms of resistance in the Jim Crow South. ${ }^{10}$ For example, in an article that is largely critical of Hurston's interpretation of the "folk," Hazel Carby has written that "Hurston's representation of the folk is not only a discursive displacement of the historical and cultural transformation of migration, but also is a creation of a folk who are outside of history" (77). ${ }^{11}$ Carby's overall project is to demystify the romanticization of Hurston's engagement with the "folk" by some feminist and postmodern scholars, a project with which I sympathize, ${ }^{12}$ but I am reluctant to conclude, with Carby, that Hurston's presentation of the "folk" is indicative of a "romantic and, it must be said, colonial imagination" (80). ${ }^{13}$ This conclusion is most plausible if one looks only at moments when Hurston finds herself in identity with her subject, as in her investigation of her home town.

Instead of viewing Hurston's work as enacting a "discursive displacement of the historical and cultural transformation of migration," I will examine the ways in which Hurston places migrant laborers within history through the Polk County section of Mules and Men; the section on Polk County, which has not received much critical attention to date, has the most to say about the link between folklore and resistance. My reassessment of Hurston's narrative frame will move beyond the relation between autobiography and ethnography to consider how she presents the relation of the teller to the tale within the company camp.

\section{A "Small Empire": Polk County, Florida}

$\mathrm{H}$ urston's departure from Eatonville, Florida, to the neighboring Polk County marked a journey from a small town in which blacks held political office to a company work camp in which migrant workers from throughout the South labored for a wage in a highly regulated living environment. Polk County promoted corporate truck farming as an investment opportunity, and the County's publicity department promoted the region as a "small empire" in which investors could expect to profit from agricultural and mining resources that could be sold throughout the eastern corridor (3; see fig. 1). "Imperial Polk," as the County commissioners described it, "stands today as an empire within herself, far more than self-supporting," and its truck farms produce an abundance, "causing the balance of trade, at the end of each year, to be greatly in her favor." The promotional pamphlet emphasizes the county's transportation infrastructure, boasting of "the most complete system of modern highways to be found in any county in the South" (3): A twopage photographic spread labeled "Highways and Motoring" displays the vanishing point of paved highway after paved highway, noting that "our system of highways is both a business asset and a most integral part of your pleasure" (6). For Hurston, however, this pleasure may have been somewhat muted, for as the pamphlet reminds 


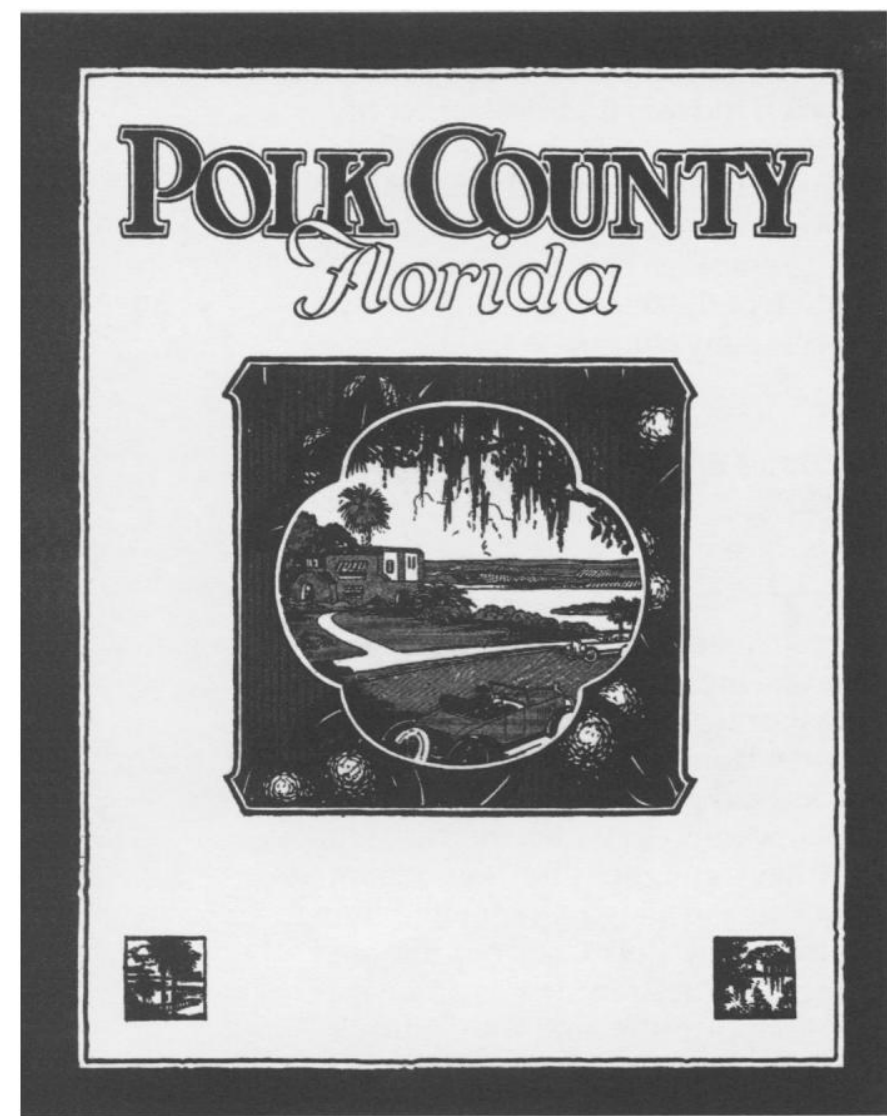

Fig. 1. Cover of Polk County,

Florida. This 24-page brochure

published by the County's publicity department encouraged investors to move to the area by citing its agricultural resources and modern highway system.

(Courtesy of the $U$ of Chicago Library.)

the reader, Polk County was segregated. These reminders nevertheless boast of the modern infrastructure available, unevenly, to both blacks and whites. In a collage of institutional buildings, a picture of the wooden Negro Hospital is shown far beneath a photograph of the brick County Hospital (2; see fig. 2), and a paragraph on public schools notes that "there are 92 schools, 65 of which are white" (17). Using the promotional material provided by the County, Hurston might have motored straight to the local golf course in search of material; the only African Americans pictured in the pamphlet are caddies.

Hurston knew better, of course. When she sees "a huge smoke-stack blowing smut against the sky" (59), she knows she'll find a source for folklore, and she enters the grounds of the
Everglades Cypress Lumber Company in Loughman. In contrast to her earlier excursion into Eatonville, in which the town and its inhabitants occupied a relatively autonomous and closed cultural sphere, Hurston has launched a collecting tour in the lumber camp because it brings together black Americans from numerous locations: "I saw at once," she observes, "that this group of several hundred Negroes from all over the South was a rich field for folk-lore" (60). Logging camps were typically staffed by migrant laborers. A 1931 study demonstrates that, due to the exhaustion of much of the Southern timber supply, the 100,000 AfricanAmerican timber workers were exceptionally mobile when Hurston visited Loughman: "In the past few years as the forests have been cut out the movement of Negro workers from one southern state to another in search of work in the lumber camps has increased" (Todes 83). ${ }^{14}$ This study notes that black workers usually held the least attractive positions:

\begin{abstract}
Negroes predominate in the turpentine camps of Georgia and Florida where exploitation of the workers is notorious. Mexican and Negro workers only are employed in the insect[-]ridden cypress swamps. To cut cypress, the workers must wade in humid swamps, often up to their hips in water, and must live with their families in house boats built over the swamps. Living quarters for Negro workers are "match-box" shacks or box cars, segregated from white workers in the towns and in the camps. Negro lumber workers share the lot of all other Negro workers in the South, in that they are discriminated against in the types of jobs given them, are paid lower wages and provided inferior housing conditions and poorer schools for their children. $(83-84)$
\end{abstract}

Hurston could have expected to gather material from semi-skilled workers from throughout the South in this camp; rather than seeking an untouched and exotic cultural sphere, Hurston examined the camp because it brought together strands of folklore from different sources. 
The "Hidden Transcript" and the Disappearing Narrator

$\mathrm{H}$ ow does Hurston experience and transcribe the "hidden transcript" of everyday resistance if she herself is an outsider? As I suggested early on, Hurston encounters resistance from the workers on the job when she first arrives. ${ }^{15}$ In these early scenes at the lumber camp, her narrative persona is present as a clumsy " $\mathrm{I}$ " who can't quite fit in: She drives a fancy car, she wears expensive clothing, and the workers suspect that she is a detective. She explains what she had to do to become part of the "inner cir-

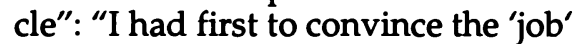
that I was not an enemy in the person of the law; and, second, I had to prove that I was their kind" (65). As she gains their trust, her narrative persona shifts more easily between first- and thirdperson. Finally, when she follows the men on the job, her narrative persona practically disappears; instead, she situates her transcribed tales in relation to conditions in the camp. Hurston learns to overcome resistance by fitting in, and her studied invisibility enables her to display folklore's power as a discourse of dissent.

The major event leading to her acceptance in the camp is her contribution to a group performance of "John Henry," a track-laying ballad. The ballad dramatizes a competition between John Henry, who is an excellent spike driver, and the steam drill his boss has procured to replace him; John Henry keeps up with the drill for an hour, until he collapses of a heart attack. The song is a parable of the manual laborer's plight under the industrial organization of work: "I'll hammer my fool self to death" (56), John Henry sings repeatedly. By contributing verses to the performance, Hurston demonstrates that she shares a cultural language with the workers on the job. The form of the ballad allows her to occupy the same subject position as the others

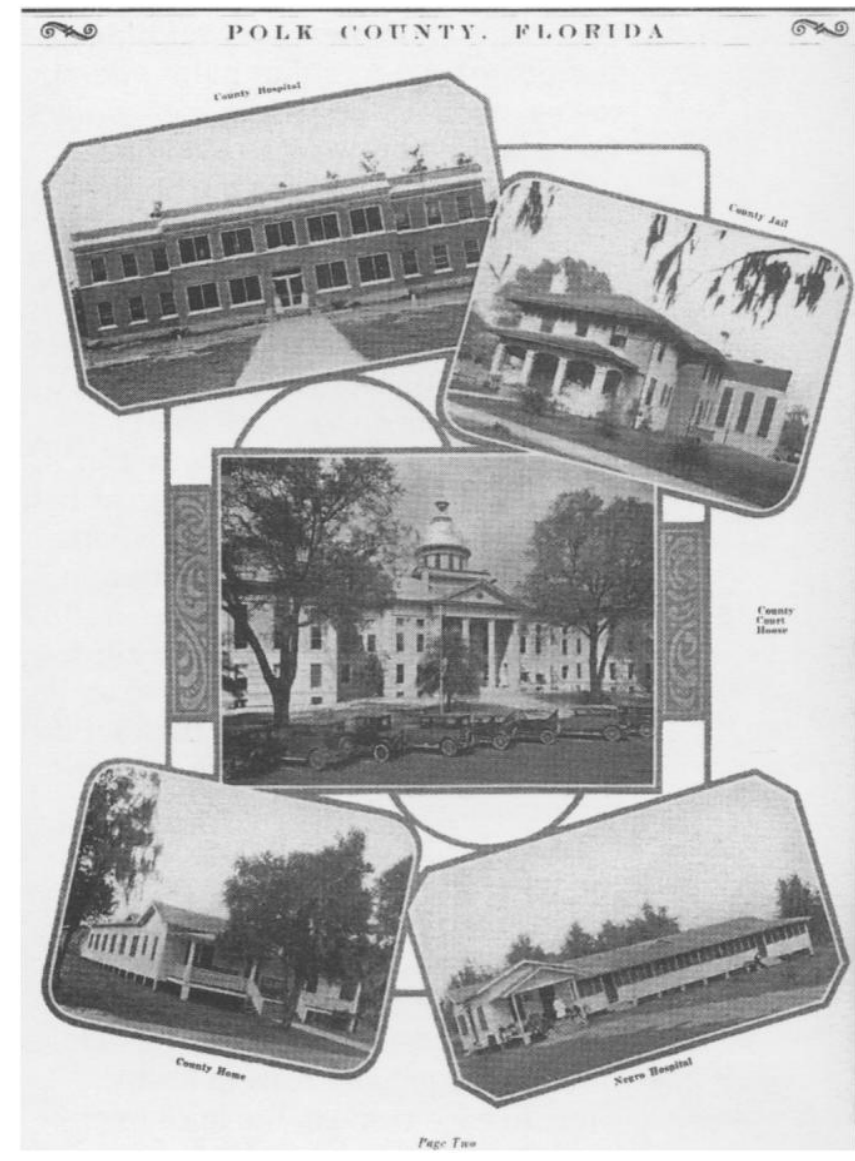

when she sings her piece, while the refrain allows all of the singers to come together as one. "John Henry" exemplifies the living language of dissent folk songs provide. As she notes in her glossary, the song's syncopation fits the rhythm of spike-driving, and this suggests that the song's origin is as a work song. In the context of the workplace, the song has operated as an articulation of beleaguered resistance to the hard work of laying down track. But Hurston does not sing the song with railroad workers: The context for this performance is a pay-day party, a social event that celebrates the receipt of wages. Here, the song serves as a reminder of workers' alienation under capitalism and of the ever-present threat of replacement by machines, while John Henry's story also serves to
Fig. 2. Polk County, Florida 2. The brochure boasts to prospective residents of its modem facilities, while stressing its segregated status: The brick County Hospital is displayed at the top of the page, the wooden Negro Hospital at the bottom.

(Courtesy of the $U$ of Chicago Library.) 
contrast with the workers' attitude on the job: John Henry dies in his attempt to best the machine, while the workers in the camp find ways to avoid labor.

Hurston's joining in the performance of "John Henry" marks a moment of transition in her narrative performance in the Polk County section of Mules and Men. Although the break is not decisive, one can detect a shift in her narrative voice from the first person to the third person. Her narration before the song concerns herself and her efforts to fit in. After she has occupied the singer's position in the ballad, however, she seems to slip more easily between first- and thirdperson narration. And, as I have earlier suggested, when she turns to describe the telling of tales on the job, she frequently slips out of view entirely.

On the following pages, I examine the ways in which Hurston presents the telling of tales in the Everglades Cypress Lumber Company as performing everyday acts of resistance.

Hurston investigates the telling of tales both on the job and during leisure time. In each context, the tales reference the presence of company supervision in the daily lives of the workers. On the job, the tales concern work and labor relations; I focus on tales about the meanness of bosses, the origins of work, and the advantage of stubborn literal-mindedness as a form of resistance. During leisure time, the workers tell tales, sing, and dance; I examine how the company both supervises and profits from the workers' time off at the jook joint. Both on the job and off, Hurston shows us, the workers use folklore as a form of resistance to the company's considerable power over their lives.

\section{Folklore and Resistance on the Job}

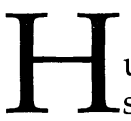
urston determines to join the swamp-gang on the job one day in order to gather more tales. As she narrates her discoveries on this day, Hurston lays out the relation between work and leisure in the camp, while she also shows how the workers employ folklore in order to interpret this relation. Hurston's study of the work day begins at dawn; she shows how the camp is transformed from its silent "dawn gray" (66) into a frenzy of activity motivated by the fear of repercussion from the boss: "Grab your dinner-bucket and hit the grit. Don't keep the straw-boss waiting" (67). The unusual circumstances of this day allow Hurston to record a number of comments and tales about the meanness of bosses. This morning the strawboss, whom Hurston identifies as a poor white section boss on the railroad, keeps the workers waiting at their appointed meeting spot. This unusual delay allows the workers the opportunity to express their resentment for their supervisors even as they speculate on the cause of the delay: One worker cynically observes that it "'must be something terrible when white folks get slow about putting us to work' "(68). Another speculates that the boss is sick, but this theory is rejected: " 'Man, he's too ugly. If a spell of sickness ever tried to slip up on him, he'd skeer it into a three weeks' spasm'" (68). The gang continues to compete for the most disparaging tale about a boss. Hurston brings together stories from disparate geographical origins to show how conversation among the migrant workers accumulates into an argument for the meanness of bosses. One worker tells of a boss from " 'Middle Georgy'" who " 'was so mean dat when the boiler burst and blowed some of the men up in the air, he docked 'em for de time they was off de job" " (69), while worker Tush Hawg attests to a boss on the east coast who " "was so mean and times was so hard till he laid off de hands of his watch" " (69). In this section, Hurston does not enter the action or participate in the tale telling; she is an omniscient observer whose reaction to the tales is subsumed in such approving phrases 
as "Everybody laughed" (68). Despite the laughter, Hurston's portrait of the beginning of the work day shows the pastoral worker's camp transformed into the site of contestation between black workers and their white bosses. In the context Hurston develops here, the competitive practice of woofing among the workers serves to build a collective discourse of resentment for the straw-boss in this camp and in other working camps across the South.

Hurston does not get to observe and record work on the swamp-gang, however, for logging has been suspended this day to allow the train to go to the Everglades to pick up a track gang. The workers erroneously conclude that they will have a day off; their conclusion is rejected by the Foreman, who tells them to go check at the mill for work, thus giving rise to the aforementioned discourse on the meanness of bosses. But the change in plans allows us to see that a day off is a rare pleasure, just as it allows us to traverse the camp to another labor site. And as the workers trudge off to the mill, two of the workers exchange "folk" tales on the origins of work that serve to explain their current predicament.

These tales place the allotment of work within a social hierarchy in which race and (sometimes) gender determine who has leisure and who is expected to do the hardest work. The first tale, "Why the Sister in Black Works Hardest," is related by Jim Allen; it is a creation myth that begins with God's creation of "de world and de varmints and de folks" " (74).

According to this tale, God completes his creation of the world by placing a bundle in the middle of the road. The bundle sits in the road for a thousand years before arousing human curiosity, but when such curiosity is aroused a division of labor is devised to determine what the bundle contains. The character called Ole Missus asks her husband, Ole Massa, to pick up the box and see what is inside. But the box appears to be too heavy, so he tells "de nigger" to get the box. He, in turn, tells his wife to get it, and " she run and grabbed a-hold of de box and opened it up and it was full of hard work" "(74). While the tale concretizes the origin of work by describing it as an object that can be concealed in a bundle, the tale also explains the social context by which the worker is compelled to do her job. Additionally, the tale offers an ironic exposition of the lure of the gift by conflating the gift with work: "De nigger 'oman" who opens the box does so with great enthusiasm, as if the box contained a gift.

Jim Allen's tale analyzes labor by relation to race and class and offers an ironic conflation of the pleasure of the gift with the burden of hard work. The chain of deferrals begins with the leisured white woman, who relies upon the wealth and prestige of her husband; in her social context, she has the least work to do. Her husband, who owns a slave, also avoids the onerous gift of work by asking the black man to satisfy his wife's curiosity. The black slave, in turn, is able to put the duty off on the black woman. In essence, the tale shows that it is the social hierarchy itself that creates alienated labor: By satisfying everyone else's curiosity and easing their burdens, the black woman assumes the greatest labor in this story.

Another worker, Jim Presley, objects to Jim Allen's tale and provides an alternative explanation for the origin of work in his tale, "'De Reason Niggers Is Working So Hard.' "

Presley's tale shares much with Allen's; the two are variations on a theme.

Presley's tale again presents the conundrum of the mysterious bundle, but this time God sets two of them on the road. The bundles are five miles down the road, and a white man and a black man race to get to the bundles. The black man runs fastest and gets there first, and he grabs the larger of the two bundles before the white man can get it. This is an unfortunate choice, for the larger bundle contains "'a pick and shovel and a hoe and a plow and chop- 
axe," "whereas the smaller bundle contains " 'a writin'-pen and ink'" (75).

Presley's tale again relates a division of labor according to race (if not gender) through a drama in which God's bundle serves to trick the black man into receiving the unpleasant gift of hard work. This moral is emphasized in the closing line of the tale: " 'So ever since then de nigger been out in de hot sun, usin' his tools and de white man been sittin' up figgerin', ought's a ought, figger's a figger; all for de white man, none for de nigger' " (75). This bleak conclusion emphasizes how the betrayed promise of God's bundle has resulted in the social exploitation of black labor.

In addition to tales on the meanness of bosses and the origins of work, Hurston witnesses a number of tales about the power of dissemblance in labor relations during her day on the gang. Deliberate literal-mindedness, lying, and foot-dragging have been consistently useful tools for AfricanAmerican workers who sought to assert some control over their work environment. In the antebellum era, Eugene Genovese has argued, these tactics asserted cumulative pressure on the institution of slavery:

\begin{abstract}
The slaves struggled to influence their own working conditions. Their actions did not challenge slavery per se, nor were they often meant to, any more than striking workers often mean to challenge the capitalist system. Yet, in an important sense the slowdowns and resistance to overwork contributed more to the slaves' struggle for survival than did many bolder individual acts that may have reflected a willingness to attack slavery itself. (621)
\end{abstract}

These tools have been codified in folktales concerning Ole Massa and John, whose origins are certainly in the antebellum era. The tales encode lessons about how to resist mastery. They remain powerful pedagogical tools in the different working conditions of the logging camp. Without imposing her own narrative voice, Hurston transcribes the men's stories as they relate them to one another. In between the stories, she describes the men's worries about getting caught by the boss telling tales on the job, and she also shows how the men slow their pace both to allow for more storytelling and to keep from getting to the mill. Hurston's juxtaposition of the narrative content of the tales with the actions of the tellers suggests that the lessons of the tales have been absorbed into the tellers' behavior.

Unlike the tales chronicling the creation of work, in which God's gift tricks the African American into acquiring the burden of work, the tales about Ole Massa and John turn the tables for the African-American figure. John, a slave, is a trickster figure who finds ways to undermine the authority of his white master, Ole Massa.

Typically, John tricks Ole Massa by adhering to a stubborn literal-mindedness that flatters the master in his expectation that his slave lacks both wit and guile. One tale in particular, "The First Colored Man in Massa's House," shows how John exploits his master's misapprehension of his cunning. As Black Baby tells the story, John is the first colored man in the country, and Ole Massa exploits John's putative lack of linguistic skills by giving him the wrong name for selected items in the house: He tells John that the fireplace is a " 'vaperator," the cat is a "round head," and the barn is "his mound" (79). When the cat catches fire from the fireplace and runs to the barn and sets the straw on fire, John runs to Ole Massa's room and relates the story in the language his master has given him. His master cannot comprehend John's message, so after several repetitions John relays the message using the correct language. By this time, the tale suggests, the fire is well under way in the barn. By playing stupid, John is able to outwit his master.

This pattern persists in the rest of the Ole Massa and John stories related this day. In "Ole Massa and John Who Wanted to Go to Heaven," Ole Massa tries to outwit John by arriving at his doorstep dressed up as God and telling 
him he has come to deliver John to heaven; John plays into the ruse by feigning fear of God until Ole Massa is coaxed into stepping far enough away from the door to allow John to bolt past him. In the "Deer Hunting Story" related by Will Richardson, Ole Massa and a slave go hunting for deer. The slave is instructed to shoot the deer after the master scares them into the slave's range of fire. The deer runs past as the slave waits, but he does not shoot; queried on his inaction, the slave responds that he had not seen any deer: " All Ah seen was a white man come along here wid a pack of chairs on his head and Ah tipped my hat to him and waited for de deer" "(75). Again, the slave's supposed guilelessness undoes the master's plan.

As I have suggested, Hurston's descriptive narrative of the men on the job signals the danger the men feel as they tell these stories of dissent. The bulk of the stories concerning Ole Massa and John are told by the swampgang as they walk from the appointed meeting spot to the mill. After the first tale concerning Ole Massa and John ("Ole Massa and John Who Wanted to Go to Heaven") is told, Hurston's narrative voice laughs and comments, "If the foreman had come along right then he would have been good and mad because he could tell their minds were not on work" (72). The workers deliberately slow their journey to the mill in order to have the time to tell more tales, and the worry caused by this tactic is on the minds of most of the swamp-gang: Jim Allen notes a need for haste before he tells his story about the origin of work; Gene Oliver asks his co-workers to hush so he can tell "What Smelled Worse" before they get to the mill; and Hurston notes that "we were at the mill at last, as slow as we had walked" (84). When they neglect to inform the mill boss of their arrival so that they can tell more tales, the tales are then framed with their expressions of worry concerning this breach of decorum. Presumably, there are at least two reasons to worry about being dis- covered exchanging tales: The men are not working, and they are also telling stories that are disparaging about white overseers. Clearly, then, the narrative frame presents a context for the stories that suggests their volatility in the present work camp. Hurston's text shows us a palpable discourse of dissent working within the company town.

\section{Folklore and Recreation in the Company Camp}

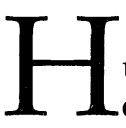
urston's text also explores the extent to which leisure time in the camp is regulated by the company. To exchange tales on the job, the men steal time from the bosses by dragging their feet. When the men have time off from work, they persist in telling stories at the fishing hole. Their time is no longer "stolen" from the company here, although the company is not far from their minds. Cliff Ulmer notes, " 'We ain't off lak dis often. Tomorrow we'll be back in de swamp 'mong de cypress knees, de 'gators, and de moccasins, and strainin' wid de swamp boss' " (114-15), and when another of the gang wonders what the swampboss is doing while the men are fishing, Cliff professes not to care. The men are intent on sharing stories, many about "varmints"; others take the form of brags about the relative fecundity of pieces of farm land owned by "my ole man" (101). Since the workers live in company-owned shacks in a corporate compound, their brags about fertile farm land are out of place. Here, their values project an alternative modernity in which their prosperity is tied to their own property rather than to the company.

Men's leisure time on the camp allows them to brag about their fictive property; in this sense, the time represents a moment of free self-expression for them. But many of the women in the camp feel that the men's free time 
is time stolen from them; the women hope for attention and household chores from the men. Mrs. Bertha Allen wants her husband Jim to do yard work, but he resists, reminding her that the yard and their shack belong to the company. His power to refuse indicates that the division between leisure and labor in "Why the Sister in Black Works Hardest" persists. This is signaled not only by Bertha Allen's request, but also by Big Sweet's intrusion at the fishing hole. Big Sweet is the vociferous girlfriend of Joe Willard, and her intrusion is mostly felt as the inappropriate interruption of men's leisure time. Joe complains, " 'We git a day off and figger we kin ketch some fish and enjoy ourselves, but naw, some wimmins got to drag behind us, even to de lake'" (124). In this section, the men's leisure time fishing provides Hurston with the opportunity to record more tales. It also provides us with an opportunity to understand leisure's rarity and its relation to gender difference.

If the company's presence is felt by the men at the fishing hole, its regulation of all of the workers' leisure time is especially marked at the jook joint. When we enter the jook joint with Hurston, we are led to believe that we are entering an autonomous cultural zone for the African-American workers in the lumber camp: We hear blues on the piano, we see couples dancing, and we watch various games in progress. Hurston's transition from the previous chapter, in which we have heard a traveling preacher's sermon, into the present one signals that the jook joint is part of life on the job: "The little drama of religion over, the 'job' reverted to the business of amusing itself" (143). Hurston calls amusement a business in part because the jook joint is where much of one's paycheck is spent, and because the jook is itself run by the company. Consequently, the same paranoia the swamp-gang felt while they exchanged tales is felt by all of the workers in the jook joint:

Somebody had squeezed the alcohol out of several cans of Sterno and added sugar, water and boiled-off spirits of nitre and called it wine. It was dealt out with the utmost secrecy. The quarters boss had a way of standing around in the dark and listening and he didn't allow a drop of likker on the job. (144)

One would be arrested and sent to jail in Bartow if caught with liquor. There is a high rate of murder on pay nights in the camp, and the banishment of alcohol is designed to prevent the loss of too many workers in this manner. In this scene, we witness a knife fight that is broken up by the quarters boss, who is predictably lurking in the shadows. He throws the knife-wielding Ella out of the jook, reminding her that she is not on the job and that "this place is for people that works on this job" " (152). While Hurston shows the workers enjoying a lively night life, she also shows how their amusements are closely watched and regulated by the company.

\section{Conclusion}

$\mathrm{H}$ joint is mostly hidden by her omniscient narrative voice. While her first days in the camp are characterized by her clumsy, obtrusive "I," her growing acceptance in the community allows her to transcribe the "hidden transcript" of everyday resistance in the camp. She records this not only by writing down the folktales that she hears, but also by setting the scene for each performance through the framing story of a day on the job. My focus on this aspect of the narrative frame in Mules and Men, and on the middle section in particular, is meant to provoke a new evaluation of the book's understanding of the exercise of power in African-American "folk" communities. The feminist and postmodern investigations of Hurston's politics have typi- 
cally focused on the ways in which the author is an embodiment of gendered and racial marginality; most of these analyses have rested on her troubling of the relation of authorial self to the ethnographic other. While these arguments have identified one important aspect of her engagement with issues of power, they have missed seeing the ways in which her text displays folklore's function as an everyday form of resistance in the Jim Crow South. Her narrative frame is far more supple than has previously been acknowledged.

Hurston's achievement comes into relief through comparison with her treatment of the same material in a later musical, Polk County. Subtitling it A Comedy of Negro Life on a Sawmill, with Authentic Negro Music, in Three Acts, Hurston reworked her Polk County fieldwork for production on the Broadway stage with Dorothy Waring in 1944 (Hemenway 298). Here, however, Hurston and her collaborator frame folklore and blues as commercially viable entertainment rather than as modes of resistance in the lumber camp. Hurston, the ethnographer, is replaced by the character of Leafy Lee, a wandering woman from New York who makes her way to Polk County to learn the blues so that she can return to the city and become famous; she encourages other characters to follow and make money in New York. ${ }^{16}$ In the musical, Leafy learns "John Henry" from Big Sweet and the others in the camp: The song culminates in an ensemble chorus in which Leafy joins and demonstrates that she is learning how to be a blues singer, in contrast to Hurston's demonstration of insider status when she sings "John Henry" in the ethnography. And Leafy does not go on the job with the men as Hurston did; that scene is cut entirely. The commercially attuned Polk County, which nonetheless was never produced, demonstrates ways in which Hurston could have diminished the political implications of folklore in the lumber camp in Mules and Men. If Hurston sought to present folklore in a "colonial, romantic" context (Carby 77), it is perhaps here that she did so, and not in Mules and Men.

If the "folk" are now inside history in Mules and Men, what claims can be made about the efficacy of their language of dissent? In Hurston's narrative, the white bosses rarely come into contact with the acts designed to resist their power. While the work of the company is certainly slowed by the gang's foot-dragging, and the quarters boss expends a lot of energy supervising the jook joint, Imperial Polk County never seems greatly threatened by the tales its migrant laborers tell. But as Genovese, Kelley, and others have argued, daily acts of resistance build communities and prepare the foundation for greater social change. In making the case for including such acts in the historical analysis of politics, Kelley writes:

\begin{abstract}
I am not suggesting that the realm of infrapolitics is any more or less important or effective than what we traditionally consider politics. Instead, I want to suggest that the political history of oppressed people cannot be understood without reference to infrapolitics, for these daily acts have a cumulative effect on power relations. (30)
\end{abstract}

The workers in the camp contributed to the political struggle for power in the Jim Crow South. Hurston's contribution in Mules and Men was not so much to write a book about herself and her own struggle for power, as the critical literature would suggest, but to transcribe the "hidden transcript" of resistance that obtained in the performance of folklore on the job.

1. Kelley's article appears in an extended and revised format in Race Rebels, chs. 1-3.

2. The term hidden transcript is borrowed from Scott. Other major influences include de Certeau and Genovese. 
3. This article is part of a book project examining the discursive uses of the "folk" in African

American culture in the early-twentieth century. I put the "folk" in quotation marks to indicate that it is the discursive figure, rather than a particular empirical group, that forms the object of study here.

4. See Wall's more extensive treatment of Hurston (particularly on the issue of the narrative frame) in Women of the Harlem Renaissance, ch. 4.

5. In this vein, see also Wainwright; Andrews. One reader who sees the feminist message as subversive, but not submerged, is Peters.

6. For important critiques of Johnson's approach, see Abel; Lurie 30-43; and Todorov.

7. One feminist study, however, reads Hurston's ethnography as replicating the structure of "containment" in the camp: "The story is a unit whose function is not to transform anyone's thoughts about his or her working conditions" (Susan Willis 44). My argument here strongly contradicts this observation.

8. See, for example, Miriam DeCosta Willis.

9. See, in particular, Dorst; Gordon; Hernández; and hooks.

10. Since I first drafted this article, other scholars have begun to explore the question of everyday resistance in Hurston's book. See, in particular, Meisenhelder.

11. But cf. Mikell, who claims that "the historical framework is implicit rather than explicit in Mules and Men" (33).

12. See Wallace (181) for another critique of the feminist mystification of Hurston.

13. Hernández concurs with my reading of Carby. We might also note, as Reed-Morrisson has, that Carby ignores the influence of Franz Boas's relativist intervention into race-centered anthropological method on Hurston's work.

14. Todes's study is aimed toward urging unionization of the workers; for another study in this vein, see Industrial Workers of the World. Despite segregation, the IWW included Negro timber workers in its ranks (see the discussion of the IWW and the Brotherhood of Timber Workers in Spero and Harris 331-32). In contrast, the U.S. Government provides a portrait of the cypress industry from the perspective of the commodity and its uses (see Neubrech). For an historical perspective from the standpoint of the capitalist manager, see Mayor.

15. This problem is also discussed in Hill 74-75.

16. Hurston and Waring 1-4-4. Typescripts of the play are archived in the New York Public Library and the Yale University Library. For a more extensive discussion of Polk County, see Lowe.

Abel, Elizabeth. "Black Writing, White Reading: Race and the Politics of Feminist Interpretation." Critical Inquiry 19.3 (1993): 470-98.

Andrews, Adrianne R. "Of Mules and Men and Men and Women: The Ritual of Talking B[l]ack." Language, Rhythm, and Sound: Black Popular Cultures into the Twenty-First Century. Ed. Joseph K. Adjaye and Andrews. Pittsburgh: $U$ of Pittsburgh P, 1997. 109-20.

Boxwell, D. A. " 'Sis Cat' as Ethnographer: Self-Presentation and Self-Inscription in Zora Neale Hurston's Mules and Men." African American Review 26 (1992): 605-17.

Carby, Hazel. "The Politics of Fiction, Anthropology, and the Folk: Zora Neale Hurston." New Essays on Their Eyes Were Watching God. Ed. Michael Awkward. Cambridge: Cambridge UP, 1990. 7193.

Clifford, James, and George E. Marcus, eds. Writing Culture: The Poetics and Politics of Ethnography. Berkeley: U of California P, 1986.

de Certeau, Michel. The Practice of Everyday Life. Trans. Steven F. Rendall. Berkeley: U of California P, 1984.

Dolby-Stahl, Sandra. "Literary Objectives: Hurston's Use of Personal Narrative in Mules and Men." Western Folklore 51 (1992): 51-63.

Dorst, John. "Rereading Mules and Men: Toward the Death of the Ethnographer." Cultural Anthropology 2 (1987): 305-18.

Genovese, Eugene D. Roll, Jordan, Roll: The World the Slaves Made. 1972. Rev. ed. New York: Vintage, 1976.

Gordon, Deborah. "The Politics of Ethnographic Authority: Race and Writing in the Ethnography of Margaret Mead and Zora Neale Hurston." Modernist Anthropology: From Fieldwork to Text. Ed. Marc Manganaro. Princeton: Princeton UP, 1990. 146-62.

Hale, Anthony R. "Framing the Folk: Zora Neale Hurston, John Millington Synge, and the Politics of Aesthetic Ethnography." Comparatist 20 (1996): 50-61. 
Harrison, Beth. "Zora Neale Hurston and Mary Austin: A Case Study in Ethnography, Literary Modernism, and Contemporary Ethnic Fiction." MELUS 21.2 (1996): 89-106.

Hemenway, Robert E. Zora Neale Hurston: A Literary Biography. Urbana: U of Illinois P, 1977. Hernández, Graciela. "Multiple Subjectivities and Strategic Positionality: Zora Neale Hurston's Experimental Ethnographies." Women Writing Culture. Ed. Ruth Behar and Deborah A. Gordon. Berkeley: U of California P, 1995. 148-65.

Hill, Lynda Marion. Social Rituals and the Verbal Art of Zora Neale Hurston. Washington: Howard UP, 1996.

hooks, bell. Yearning: Race, Gender, and Cultural Politics. Boston: South End P, 1990.

Hurston, Zora Neale. Mules and Men. 1935. New York: HarperPerennial, 1990.

-, and Dorothy Waring. Polk County: A Comedy of Negro Life on a Sawmill, with Authentic Negro Music, in Three Acts. Typescript, 1944.

Industrial Workers of the World. The Lumber Industry and Its Workers. 3d ed. Chicago: Industrial Workers of the World, ca. 1922.

Johnson, Barbara. "Thresholds of Difference: Structures of Address in Zora Neale Hurston." "Race," Writing, and Difference. Ed. Henry Louis Gates, Jr. Chicago: U of Chicago P, 1986. 317-28.

Jordan, Rosan Augusta. "Not into Cold Space: Zora Neale Hurston and J. Frank Dobie as Holistic Folklorists." Southern Folklore 49 (1992): 109-31.

Kelley, Robin D. G. Race Rebels: Culture, Politics, and the Black Working Class. 1994. New York: Free $\mathrm{P}, 1996$.

-. " 'We Are Not What We Seem': Rethinking Black Working-Class Opposition in the Jim Crow South." Journal of American History 80.1 (1993): 75-112.

Lowe, John. "From Mule Bones to Funny Bones: The Plays of Zora Neale Hurston." Southern Quarterly 33.2-3 (1995): 65-78.

Lurie, Susan. Unsettled Subjects: Restoring Feminist Politics to Poststructuralist Critique. Durham: Duke UP, 1997.

Mayor, Archer H. Southern Timberman: The Legacy of William Buchanan. Athens: U of Georgia P, 1988.

Meisenhelder, Susan. "Conflict and Resistance in Zora Neale Hurston's Mules and Men." Journal of American Folklore 109 (1996): 267-88.

Mikell, Gwendolyn. "The Anthropological Imagination of Zora Neale Hurston." Western Journal of Black Studies 7.1 (1983): 27-35.

Neubrech, W. LeRoy. American Southern Cypress. Washington: United States Government Printing Office, 1939.

Peters, Pearlie. "Women and Assertive Voice in Hurston's Fiction and Folklore." Literary Griot 4.1-2 (1992): 100-10.

Polk County, Florida. Bartow, Florida: Polk County Publicity Department, ca. 1928.

Reed-Morrisson, Laura. "'Money and Fun and Foolishness': Rethinking Work and Play in Mules and Men and Their Eyes Were Watching God." Typescript, 1994.

Sánchez-Eppler, Benigno. "Telling Anthropology: Zora Neale Hurston and Gilberto Freyre Disciplined in Their Home-Field-Work." American Literary History 4.3 (1992): 464-88.

Scott, James C. Domination and the Arts of Resistance: Hidden Transcripts. New Haven: Yale UP, 1990.

Spero, Sterling D., and Abram L. Harris. The Black Worker: The Negro and the Labor Movement. 1931. New York: Atheneum, 1968.

Todes, Charlotte. Labor and Lumber. New York: International, 1931.

Todorov, Tzvetan. " 'Race,' Writing, and Culture." "Race," Writing, and Difference. Ed. Henry Louis Gates, Jr.. Chicago: U of Chicago P, 1987. 370-80.

Wainwright, Mary Katherine. "Subversive Female Folk Tellers in Mules and Men." Zora in Florida. Ed. Steve Glassman and Kathryn Lee Seidel. Orlando: U of Central Florida P, 1991. 62-75.

Wald, Priscilla. "Becoming 'Colored': The Self-Authorized Language of Difference in Zora Neale Hurston." American Literary History 2.1 (1990): 79-100.

Wall, Cheryl A. "Mules and Men and Women: Zora Neale Hurston's Strategies of Female Empowerment." Black American Literature Forum 23 (1989): 661-80.

-. Women of the Harlem Renaissance. Bloomington: Indiana UP, 1995.

Wallace, Michele. Invisibility Blues: From Pop to Theory. New York: Verso, 1990.

Willis, Miriam DeCosta. "Folklore and the Creative Artist: Lydia Cabrera and Zora Neale Hurston." CLA Journal 27.1 (1983): 81-90.

Willis, Susan. Specifying: Black Women Writing the American Experience. Madison: U of Wisconsin P, 1987. 